Dr David Robie was editor of the Melbourne Sunday Observer (1969-1970), one of the newspapers to feature Burchett as foreign correspondent.

\section{Public Enemy Number}

\section{One's global journalism}

Rebel Journalism: The Writings of Wilfred Burchett, edited by George Burchett and Nick Shimmin; foreword by John Pilger. Melbourne, Cambridge University Press, 2007, 314 pp. ISBN 9780521718264

$\mathrm{W}$ ILFRED BURCHETT’S legendary 'warning to the world' eyewitness account in the Daily Express, exposing the horror of the United States nuclear genocide in Hiroshima and Nagasaki, made global headlines on 5 September 1945. Almost four decades later, in his final book, Shadows of Hiroshima, he returned to this nuclear nightmare and reflected on this racist experiment against an already defeated enemy and a history of cover-ups over the 'atomic plague'.

A few weeks after typing the last footnotes for the book in Sofia,

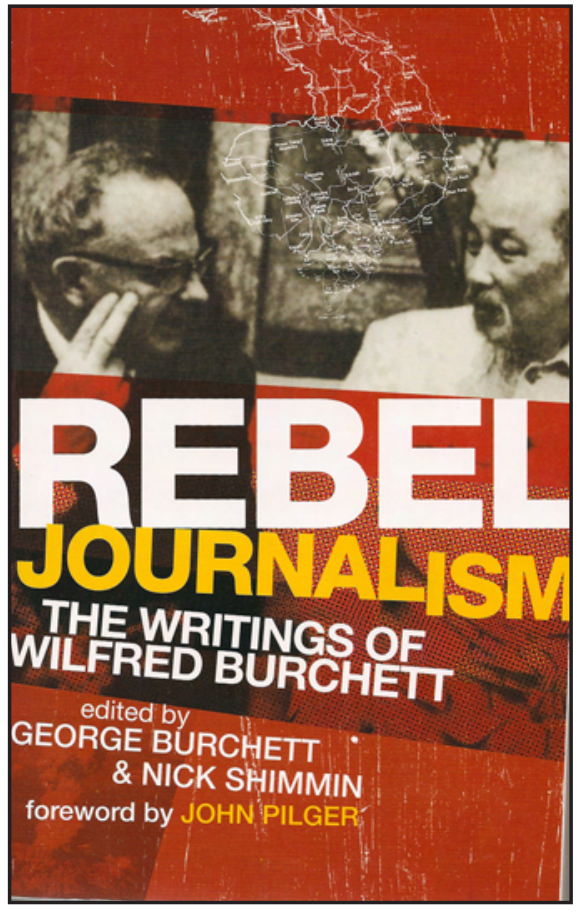

Bulgaria, he suffered a stroke and died aged 72 on 26 September 1983. This last of 31 books in an extraordinary journalism career was written at a gloomy time for the Left globally. The Soviet Union was bogged down in its own 'Vietnam' in Afghanistan, victorious Vietnam had become isolated as a totalitarian Stalinist regime, and Western countries were supporting the genocidal Khmer Rouge in Cambodia.

Aghast at China's backing for the Khmer Rouge and for reactionary struggles in Southern Africa, Burchett's message for the 
world and for independent journalists was simple as the Cold War was drawing to a close:

The 'lesson' of Hiroshima is, in my opinion, actually twofold. On the one hand Hiroshima, like Auschwitz, asserts the existence of the will to genocidal, absolute destruction. We should never cease to meditate on the fact that there has already occurred a first nuclear war, and, because of this precedent, there is little reason to doubt the possibility of a secondparticularly if the same constellation of class interests, will-to-power and mind-numbing rhetoric that authorized the exemplary immolation of Hiroshima and Nagasaki is again given pretext and opportunity.

On the other hand, Hiroshima also represents the indestructibility of human resistance. Despite their ordeals, the cover-ups, even the ostracism from 'normal' society, the hibakusha survivors have fought back, becoming the most stalwart and militant of peaceniks. Through them and their ongoing struggle, the urgency of Hiroshima is transmitted to all of us. (p. 305)

Arguably Australasia's most controversial and hated journalist, Burchett has remained the subject of debate and research long after his death. In my review of his autobiography (Burchett \& Shimmin, 2005), com- pleted by his brother George long after his death, I commented on the Sunday Observer's role in arranging a charter aircraft from New Caledonia to fly Burchett to Australia in an attempt to regain his birthright (Robie, 2006). This was after his Australian passport had been stolen by the CIA some two decades earlier (Burchett, 1969) and a vendetta by a paranoid Canberra bureaucracy had barred him entry to his homeland ever since.

My newspaper, campaigning in opposition to the Vietnam War, had recruited Burchett as chief Southeast Asian affairs correspondent. We were honoured to have him on board. To us, he was distinguished, courageous and heroic as an independent journalist.

However, many Australian critics_-including quite a number of journalists-loathed him as a communist propagandist, or branded him as a traitor. For them, he was Public Enemy Number One.

Hosting Burchett at our terraced house in Carlton, we found him charming, insightful and a down-toearth scribe who believed in social justice and had been disturbed by Nazi fascism and the horror of Hiroshima. His mission was to balance the hypocrisy and propaganda of the West - the antithesis of the 'embedded' journalist of today. 
After the Sunday Observer's success at bringing Burchett back to Australia, he fought to clear his name in a defamation case in which he won a pyrrhic victory. The court ruled he had been defamed, but that the defamation was protected by parliamentary privilege. As John Pilger writes in the foreword to this book, Burchett paid a high price for reporting from the 'other side' during the Cold War.

For 17 years, he and his children were denied passports by the Australian government. No charges were brought against him; no 'crime' was ever stated ... When later, an Australian judge described the smearing of Wilfred as a 'miscarriage of justice', he spoke the truth. (p. xiii)

As costs were awarded against Burchett and he was unable to pay, his search for justice ended with his exile becoming permanent.

In a second foreword by professor Gavan McCormack, who likened the Burchett case to an 'Australian Dreyfus', says no intelligence file gathered against a journalist could be 'more revealing of the foibles, obsessions, cruelty and petty-mindedness of a generation of Australian politicians and bureaucrats' (p. xvi). He adds:

One of the paradoxes of 20th century Australia was that the man who stirred greater public hatred and abuse than any other should also have been one who embodied its supposed core values: independent mindedness, multiculturalism (long before the word became familiar), pragmatism, love of argument and of food, and a preference always for the common man and the underdog against authority. (p. xv)

As well as covering one of the greatest scoops of last century-his exclusive solo report blowing the coverup of Hiroshima and describing the terrible effects from radiation on the civilian victims-Burchett covered major conflicts and momentous political occasions for more than four decades. In retaliation for his Hiroshima report, he was issued with an expulsion order by the US. Japanese film footage of the 'atomic plague' was classified top secret and barred from public access until 1968.

This book is an anthology of his work from the Second World War onwards. Thirty book chapters and essays chronicle world-changing events from The Atomic Plague (1945) until an Afterword (1983) when he reflected on the global nuclear threat. One chapter, slightly out of sequence, With Mick Griffith to the Plaine des Lacs (1941), deals with a vast nickel minefield in New Caledonia and reveals how strategically important 
New Caledonia would be in a war with Japan.

Other chapters include the trial of Cardinal Mindszenty (1951) in postwar Hungary - the first indictment of a cardinal in Europe since Cardinal Wolsey in England in 1530; The Microbe War (1953) about allegations of biological warfare in Korea; Front-line Village (1959), where he described a journey through frontline villages in Laos; Gagarin (1961), an exclusive interview with the Soviet cosmonaut Yuri Gagarin; War Against Trees (1963), about the US use of chemical spraying to destroy the environment and food crops in Vietnam; The Tet of Peace (1973/1977) and How to be a Good Khmer Rouge (1981), one of the earliest exposes of the genocidal Pol Pot regime.

Although Burchett wrote about the Cold War era, a remarkable impression about this volume is how many of his analyses and insights could easily apply to contemporary times. For example, there are critical parallels between the US-led invasion and occupation of Iraq and the Vietnam War.

This book is a valuable contribution to the study of journalism, social justice and contested issues of ethics, fairness and objectivity.

\section{References}

Burchett, G., and Shimmin, N. (2005). Memoirs of a rebel journalist: The autobiography of Wilfred Burchett. Sydney: UNSW Press.

Burchett, W. (1983). Shadows of Hiroshima. London: Verso.

Burchett, W. (1969). Passport: An autobiography. London: Nelson.

Burchett, W. (1959). Mekong upstream: A visit to Laos and Cambodia. Berlin: Seven Seas Publishers.

Robie, D. (2006). Behind the bitter attacks and propaganda-a remarkable Cold War talent. Pacific Journalism Review, 12(2), pp. 192-196. 